ISSN 0258-7122

Bangladesh J. Agril. Res. 35(1) : 113-124, March 2010

\title{
EFFECT OF DROUGHT ON PHYSIOLOGY AND YIELD CONTRIBUTING CHARACTERS OF SUNFLOWER
}

\author{
M. I. HOSSAIN ${ }^{1}$, A. KHATUN ${ }^{2}$, M. S. A. TALUKDER ${ }^{3}$ \\ M. M. R. DEWAN ${ }^{4}$ AND M. S. UDDIN ${ }^{5}$
}

\begin{abstract}
The present study was conducted during 1995 to April 1996 at Bangladesh Agricultural University, Mymensingh to investigate the effect of drought stress at various levels with a view to studying the physiological characters of sunflower associated with yield under drought condition. Two varieties ( Kironi and Hysan-55) and five drought cycles were i) Daily watering, ii) 1 day without water, iii) 2 days without water, iv) 3 days without water, and v) 4 days without water imposed in the study. As a whole, drought treatment reduced the yield and yield contributing characters of sunflower. In most cases, the rate of reduction was higher in plants that received 4 days drought cycle followed by 3 days. The minimum reduction was observed in plants that received 1 and 2 days drought cycle. The growth parameters (CGR, RGR, NAR, and LAI) were reduced under drought treatments. Similar trend was followed in case of CSI values and RWC of the leaves. The rate of reduction for most of characters was higher in Hysan55 than that of Kironi. Thus, the variety Kironi was found better than Hysan-55 in respect of physiological adaptation associated with yield under drought condition.
\end{abstract}

Keywords: Drought, physiology, sunflower.

\section{Introduction}

Sunflower (Helianthus annuus L.) occupies the fourth most important oil seed crop in the world. It is grown as a source of vegetable oil and protein. The acute shortage of edible oil in the country is increasing every year with increasing population growth. This large shortage, however, may be reduced by increasing yield through appropriate application of fertilizer and irrigation, proper management or by introducing drought resistant varieties of sunflower. New varieties must be developed that can withstand adverse climatic conditions particularly the soil moisture stress in order to produce higher yield. From various studies, it has been observed that physiological attributes of plants depend on improving the drought resistance of crop cultivar that have maximum seed yield, maximum head diameter, maximum physiological adaptability, and high growth rate. Hence, the present study was undertaken to investigate the physiological adaptation associated with yield attributes to different levels of drought in sunflower.

\footnotetext{
${ }^{1}$ Bangladesh Tea Research Institute, Panchagarh ${ }^{2,} 3$ \& ${ }^{4}$ RFS Division, Bangladesh Rice Research Institute, Gazipur, ${ }^{5}$ DAE, Khamarbari, Dhaka, Bangladesh.
} 


\section{Materials and Method}

The experiment was carried out at the potyard of the Bangladesh Agricultural University, Mymensingh from November 1995 to April 1996. The soil was a sandy loam with $\mathrm{pH}(6.8)$, total $\mathrm{N}(0.12 \%)$, available P (19 ppm), exchangeable K (0.36 m.eq./ $100 \mathrm{~g})$, available S (10 ppm), organic carbon (0.8\%), and organic matter (1.38\%). The field capacity of the soil was 32\% (dry basis). Two varieties of sunflower (Helianthus annuus L.) were Kironi (DS-l) and Hysan-55 was used for the study. The collected soils were well-pulverized and dried. Each pot was filled in with $8 \mathrm{~kg}$ soil. Three seeds of each variety were sown in each pot on 30 November 1995. Seedling emergence was recorded within 7-8 days. One healthy seedling per pot was allowed to grow when seedlings were $10-12 \mathrm{~cm}$ in height. The seedlings were considered established at 30 days after sowing. Five-drought treatments, viz., daily watering (D), one day without water (1), two days without water (2), three days without water (3), and four days without water (4) were tested. The experiment was conducted in a factorial Randomized Complete Block Design with three replications. Sixty seedlings of each variety were established of which 15 seedlings were randomly selected at each harvest. A total of four harvests were made. Irrigation was applied upto its filled capacity level in each pot of each treatment received optimum moisture at growing medium. An estimate was made by randomly selected three pots of each treatment and watering them slowly until water leached from the base. After two hours, the leached water was measured and subtracted from the original volume applied. The average volume of water applied to the three pots was considered to be the optimum pot capacity and this volume was given to all other pots of the same treatment.

\section{Data collection:}

a) Physiological parameters:

i) $L A I=\frac{L A}{P}$ (Rawson and Turner,1982). LAI was measured at 45, 60, and 75 days after sowing (DAS).

ii) $C G R=\frac{W_{2}-W_{1}}{T_{2}-T_{1}}$ (The rate of increase in dry weight per unit area of land is crop growth rate i.e., absolute growth rate of the plant).

iii) $R G R=\frac{L n \cdot W_{2}-L n \cdot W_{1}}{T_{2}-T_{1}}$ (Crop growth rate and relative growth rate were calculated at an interval of 15 days during 45-60 DAS and 60-75 DAS). 
iv) $N A R=\frac{W_{2}-W_{1}}{T_{2}-T_{1}} \times \frac{L n \cdot L A_{2}-L n L A_{1}}{L A_{2}-L A_{1}}$ (The net assimilation rate was calculated during 45-60 and 60-75 DAS).

Where, $\mathrm{W}_{1}=$ Total dry weight at time $\mathrm{T}_{1}, \mathrm{~W}_{2}=$ Total dry weight at time $\mathrm{T}_{2}, \mathrm{~L}_{\mathrm{n}}=$ Natural logarithm, $\mathrm{LA}_{1}=$ Leaf area at time $\mathrm{T}_{1}, \mathrm{LA}_{2}=$ Leaf area at time $\mathrm{T}_{2}, \mathrm{P}=$ Ground area and LA = Leaf area.

v) $C S I=\frac{O D \text { value of heated sample }}{O D \text { value of unheated sample }} \times 100$ (The CSI was used as a measuring method to differentiate between drought resistant and drought susceptible variety. A laboratory method was described by Kaloyereas (1958) that determine the drought hardiness based on the thermo-stability of chlorophyll pigments when kept in a hot water bath for an hour. The more stable the chlorophyll, the hardier the plant.

vi) $R W C=\frac{\text { Fresh wegiht }- \text { Dry weight }}{\text { Turgid weight }- \text { Dry weight }} \times 100$, RWC is an important determinant of metabolic activity and survival of leaf (Sinclair and Ludlow, 1987). The relative water content was measured in a day on which specific stress treatments were due to receive irrigation.

b) Root characters (Root volume, Tap root and total root length) were measured

c) Seed yield and yield contributing characters (Total number of seeds per head, 100-seed weight (g), and seed yield/plant (g))

The data were analyzed statistically and means were compared by the Duncan's Multiple Range Test (Gomez and Gomez, 1984).

\section{Results and Discussion}

Leaf area index: Drought cycle showed significant difference in different days after sowing where daily watering produced significantly highest LAI at all the stages in variety Hysan than Kironi. From Table 1, it was also revealed that both the varieties produced increased LAI upto 75 DAS.

Among the interactions between drought and varieties, it was found that the rate of reduction in variety Kironi under daily watering to 1, 2, 3, and 4-day drought cycles were $2.70,10.81,16.21$, and 22.97 percent at 45 DAS and 5.19,10.85,16.04 and 24.06 percent at 60 DAS; 4.08, 9.85, 15.86, and 25.95 percent at 75 DAS; whereas variety Hysan-55, the values were 7.23, 13.25, 24.10, and 43.37 percent at 45 DAS; 4.55, 13.18, 23.18, and 37.72 percent at $60 \mathrm{DAS}$; and 5.71, 22.6, 27.17, and 42.23 percent at 75 DAS, respectively. Daily watering showed highest LAI at all the growth stages in case of variety Hysan than Kironi. 
Table 1. Effect of drought cycles on leaf area index in sunflower cultivar.

\begin{tabular}{|c|c|c|c|}
\hline \multirow{2}{*}{ Treatments } & \multicolumn{3}{|c|}{ Days after sowing (DAS) } \\
\hline & 45 & 60 & 75 \\
\hline \multicolumn{4}{|l|}{ Drought cycle } \\
\hline $\mathrm{D}$ & $0.79 \mathrm{a}$ & $2.16 \mathrm{a}$ & $4.27 \mathrm{a}$ \\
\hline 1 & $0.75 \mathrm{~b}$ & $2.05 \mathrm{~b}$ & $4.06 \mathrm{~b}$ \\
\hline 2 & $0.69 \mathrm{c}$ & $1.90 \mathrm{c}$ & $3.72 \mathrm{c}$ \\
\hline 3 & $0.62 \mathrm{~d}$ & $1.73 \mathrm{~d}$ & $3.34 \mathrm{~d}$ \\
\hline 4 & $0.52 \mathrm{e}$ & $1.49 \mathrm{e}$ & $2.80 \mathrm{e}$ \\
\hline LSD (0.05) & 0.012 & 0.038 & 0.085 \\
\hline \multicolumn{4}{|l|}{ Variety } \\
\hline Kironi & 0.66 & 1.88 & 3.7 \\
\hline Hysan-55 & 0.68 & 1.85 & 3.58 \\
\hline 't' value & $* *$ & $* *$ & $* *$ \\
\hline \multicolumn{4}{|l|}{ Drought x Variety } \\
\hline D-Kironi & $0.74 \mathrm{c}$ & $2.12 \mathrm{~b}$ & $4.16 \mathrm{~b}$ \\
\hline D-Hysan & 0.83 a & $2.2 \mathrm{a}$ & $4.38 \mathrm{a}$ \\
\hline 1-Kironi & $0.72 \mathrm{~d}$ & $2.01 \mathrm{c}$ & 3.99 c \\
\hline 1-Hysan & $0.77 \mathrm{~b}$ & $2.10 \mathrm{~b}$ & $4.13 \mathrm{~b}$ \\
\hline 2-Kironi & $0.66 \mathrm{e}$ & $1.89 \mathrm{~d}$ & $3.75 \mathrm{~d}$ \\
\hline 2-Hysan & $0.72 \mathrm{~d}$ & $1.91 \mathrm{~d}$ & $3.39 \mathrm{~d}$ \\
\hline 3-Kironi & $0.62 \mathrm{~g}$ & $1.78 \mathrm{e}$ & 3.50 e \\
\hline 3-Hysan & $0.63 \mathrm{f}$ & $1.69 \mathrm{f}$ & $3.19 \mathrm{f}$ \\
\hline 4-Kironi & $0.57 \mathrm{~h}$ & $1.61 \mathrm{~g}$ & $3.08 \mathrm{f}$ \\
\hline 4-Hysan & $0.47 \mathrm{i}$ & $1.37 \mathrm{~h}$ & $2.53 \mathrm{~g}$ \\
\hline LSD (0.05) & 0.005 & 0.054 & 0.121 \\
\hline
\end{tabular}

$\mathrm{D}=$ Daily watering, $1=1$ day without water, $2=2$ days without water, $3=3$ days without water, $4=4$ days without water.

The leaf area index (LAI) increased gradually in sunflower from seedling to flowering. With the increasing LAI, dry matter production was also increased due to greater sunlight absorption until the foliage becomes sufficiently dense to be mutually shaded. Similar results were also reported by Arnon (1975). Several analysis suggested that water deficit have notable effect on leaf area than on photosynthetic rate per unit area which ultimately reduce the grain yield. 
Crop growth rate and relative growth rate (CGR and RGR): The data are presented in Table 2. CGR was found to increase with the age of the plant. Among the treatments, dailywatered plants produced the highest CGR and the lowest CGR was found in 4-day drought. There was trend to decrease CGR with the increase of drought cycle in 45-60 DAS. Similar trend was followed in 60-75 DAS. Overall, Hysan variety showed higher CGR in 45-60 and 60-75 DAS than Kironi.

Table 2. Effect of drought cycles on CGR, RGR, and NAR per plant of sunflower cultivar.

\begin{tabular}{|c|c|c|c|c|c|c|}
\hline \multirow[b]{2}{*}{ Treatments } & \multicolumn{2}{|c|}{ CGR/plant (mg/day) } & \multicolumn{2}{|c|}{ RGR (mg/g/day) } & \multicolumn{2}{|c|}{ NAR (mg/dm²/day) } \\
\hline & $\begin{array}{c}45-60 \\
\text { days }\end{array}$ & $\begin{array}{c}\begin{array}{c}60-75 \\
\text { days }\end{array} \\
\end{array}$ & $\begin{array}{c}45-60 \\
\text { days }\end{array}$ & $\begin{array}{c}\begin{array}{c}60-75 \\
\text { days }\end{array} \\
\end{array}$ & $\begin{array}{c}45-60 \\
\text { days }\end{array}$ & $\begin{array}{c}\begin{array}{c}60-75 \\
\text { days }\end{array} \\
\end{array}$ \\
\hline \multicolumn{7}{|l|}{ Drought cycle } \\
\hline $\mathrm{D}$ & 745.6 a & 1295.8 a & $96.49 \mathrm{~b}$ & $56.49 \mathrm{ab}$ & $111.4 \mathrm{a}$ & 85.04 a \\
\hline 1 & $673.0 \mathrm{~b}$ & $1240.9 \mathrm{~b}$ & $96.18 \mathrm{~b}$ & 58.52 a & $106.2 \mathrm{~b}$ & 85.73 a \\
\hline 2 & 609.l c & 1116.l e & $96.37 \mathrm{~b}$ & 58.35 a & $103.8 \mathrm{~b}$ & $83.87 \mathrm{ab}$ \\
\hline 3 & $546.2 \mathrm{~d}$ & $973.1 \mathrm{~d}$ & $97.17 \mathrm{~b}$ & 57.33 а & $102.5 \mathrm{~b}$ & 80.91 b \\
\hline 4 & $467.7 \mathrm{e}$ & $764.0 \mathrm{e}$ & $102.4 \mathrm{a}$ & $54.86 \mathrm{~b}$ & $103.8 \mathrm{~b}$ & 74.9 c \\
\hline LSD (0.05) & 27.45 & .42 .14 & 3.091 & 2.01 & 4.069 & 3.34 \\
\hline \multicolumn{7}{|l|}{ Variety } \\
\hline Kironi & 579.9 & 1054.5 & 97.08 & 58.13 & 106.9 & 79.62 \\
\hline Hysan-55 & 636.7 & 1101.4 & 98.37 & 56.03 & 110.1 & 84.50 \\
\hline 't' value & * & $*$ & NS & $*$ & $*$ & $*$ \\
\hline \multicolumn{7}{|l|}{ Drought x Variety } \\
\hline D-Kironi & $671.3 \mathrm{e}$ & $1224 \mathrm{~b}$ & 96.66 a & 58.16 & 104.2 bc & $82.33 \mathrm{~b}$ \\
\hline D-Hysan & 819.8 a & 1367 a & 96.32 a & 54.82 & 118.7 a & 87.75 a \\
\hline 1-Kironi & 630.9 e & $1160 \mathrm{c}$ & 96.90 a & 58.53 & $102.5 \mathrm{e}$ & $81.74 \mathrm{~b}$ \\
\hline 1-Hysan & $715.1 \mathrm{~b}$ & $1322 \mathrm{a}$ & $95.45 \mathrm{a}$ & 58.51 & $109.8 \mathrm{~b}$ & $89.71 \mathrm{a}$ \\
\hline 2-Kironi & $583.3 \mathrm{~d}$ & $1076 \mathrm{~d}$ & 96.88 a & 58.69 & 101.5 c & $80.76 \mathrm{~b}$ \\
\hline 2-Hysan & 634.9 c & $1156 \mathrm{e}$ & $95.85 \mathrm{a}$ & 58.01 & 106.2 bc & 86.96 a \\
\hline 3-Kironi & $541.4 \mathrm{e}$ & $974 \mathrm{e}$ & 96.99 a & 57.80 & $99.1 \mathrm{c}$ & 77.7 be \\
\hline 3-Hysan & 552.0 de & $972 \mathrm{e}$ & $97.36 \mathrm{a}$ & 56.86 & 105.0 be & 83.9 ab \\
\hline 4-Kironi & $473.6 \mathrm{f}$ & $838 \mathrm{f}$ & $97.97 \mathrm{a}$ & 57.47 & $96.1 \mathrm{~cd}$ & 75.39 be \\
\hline 4-Hysan & $461.8 \mathrm{f}$ & $690 \mathrm{~g}$ & $89.78 \mathrm{~b}$ & 52.25 & $101.2 \mathrm{e}$ & 74.39 e \\
\hline LSD (0.05) & 38.81 & 59.59 & 4.37 & NS & 5.74 & 4.27 \\
\hline
\end{tabular}

$\mathrm{D}=$ Daily watering, water. $1=1$ day without water, $2=2$ days without water, 33 days without water, $4=4$ days without water.

Among the interactions between varieties and drought, the rate of reduction in variety Hysan-55 under daily watering to $1,2,3$, and 4 days drought cycles were 12.77 to 43.66 percent during 45-60 DAS and 3.29 to 49.52 percent during 60-75 DAS, whereas in variety Kironi, the values were 6.02 to 29.48 percent 
during 45-60 DAS; 5.23 to 31.53 percent during 60-75 DAS. Dougherty (1973) found that water stress reduced the crop growth rate and the length of growing period which ultimately reduced the total yield.

RGR: The RGR was found significantly higher at the early vegetative growth during 45-60 DAS and then declined at 60-75 DAS irrespective of the varieties and drought treatments. This was the general trend of diminishing RGR values with the age of the crops, because of the distributions of increased periodic dry matter on the total cumulated dry matter. Only the highest drought treatments i.e. 4-day drought showed significantly lower RGR in variety Hysan-55 and the variety Kironi did not reduce RGR significantly even in the drought treatments. These results agreed with that of Gimenez and Fereres (1987) in sunflower crops.

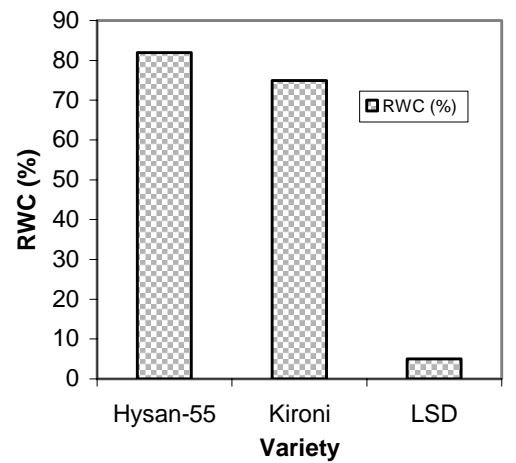

a

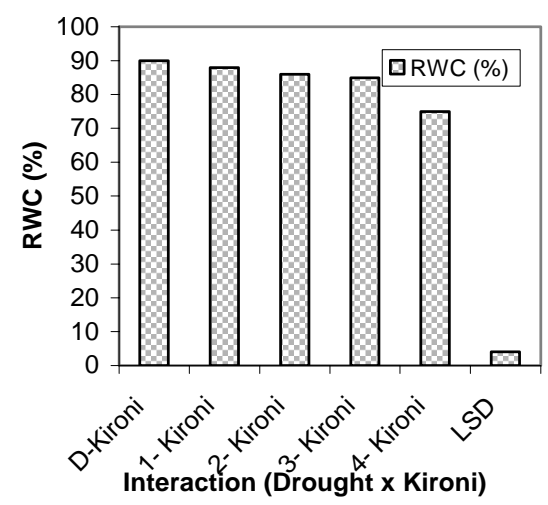

C

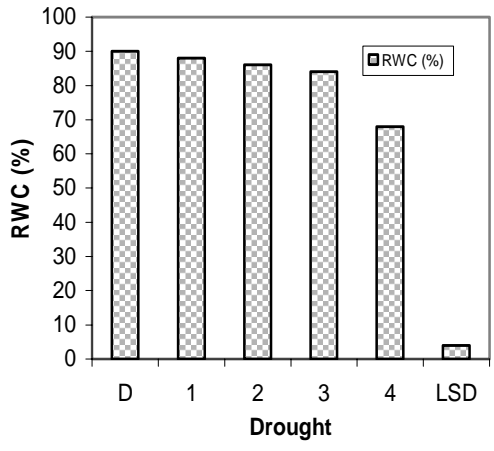

b

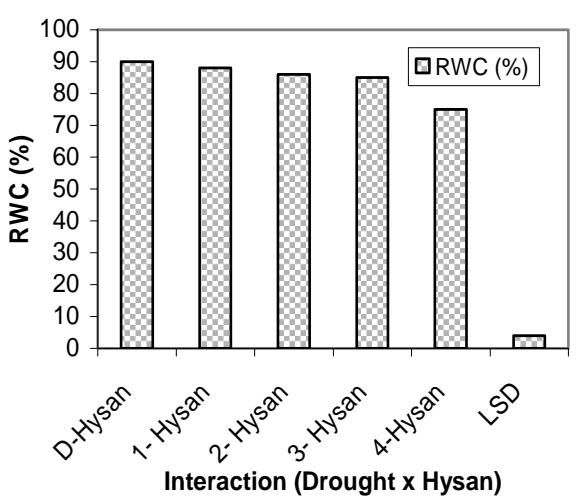

d

Fig. 1. Chlorophyll Stability Index (CSI) values (\%) for (a) Variety (b) Drought (c) Drought X Variety Kironi, (d) Drought X Variety Hysan-55.

LSD $(0.05)$ value for Variety $=33.01$

LSD (0.05) value for Drought $=2.08$

LSD (0.05) value for Drought $x$ Variety $=2.80$ 
Net assimilation rate (NAR): It was revealed that the plants of the earlier harvest (45-60 DAS) showed higher NAR values than the late harvests between 60 and 75 DAS (Table 2). Daily watered showed highest NAR at 45-60 DAS, but statistically at par to D, 1 \&2 at 60-75 DAS. The variety Hysan-55 showed highest NAR at 40-60 \& 60-75 DAS. Variation in NAR was found insignificant in the variety Kironi under different water stress treatments and daily-watered plants. But the variety Hysan-55 showed significant reduction in NAR under 4day drought cycle compared to daily-watered plants. Morizet et al. (1984) also observed lower NAR in sunflower under drought condition.

Table 3. Effect of drought on root volume, tap root length and total root length per plant in sunflower cultivar.

\begin{tabular}{|c|c|c|c|}
\hline Treatments & $\begin{array}{l}\text { Root volume } \\
\text { at maturity (g/ee) }\end{array}$ & $\begin{array}{c}\text { Tap root } \\
\text { length/plant } \\
\text { at maturity }(\mathrm{cm})\end{array}$ & $\begin{array}{c}\text { Total root } \\
\text { length/plant } \\
\text { at maturity }(\mathrm{m})\end{array}$ \\
\hline $\begin{array}{l}\text { Drought cycle } \\
\text { D } \\
1 \\
2 \\
3 \\
4\end{array}$ & $\begin{array}{l}42.11 \mathrm{a} \\
40.16 \mathrm{~b} \\
37.17 \mathrm{c} \\
32.92 \mathrm{~d} \\
28.80 \mathrm{e}\end{array}$ & $\begin{array}{l}21.26 \\
19.99 \\
17.64 \\
16.33 \\
13.49\end{array}$ & $\begin{array}{l}74.57 \mathrm{~b} \\
78.57 \mathrm{a} \\
74.87 \mathrm{~b} \\
62.81 \mathrm{c} \\
55.31 \mathrm{~d}\end{array}$ \\
\hline LSD (0.05) & 1.029 & NS & 3.144 \\
\hline $\begin{array}{l}\text { Variety } \\
\text { Kironi } \\
\text { Hysan-55 } \\
\end{array}$ & $\begin{array}{l}32.53 \\
39.93 \\
\end{array}$ & $\begin{array}{l}17.58 \\
17.91 \\
\end{array}$ & $\begin{array}{l}74.67 \\
63.78 \\
\end{array}$ \\
\hline "t value" & $*$ & $*$ & $*$ \\
\hline $\begin{array}{l}\text { Drought x Variety } \\
\text { D-Kironi } \\
\text { D-Hysan } \\
\text { 1-Kironi } \\
\text { l-Hysan } \\
\text { 2-Kironi } \\
\text { 2-Hysan } \\
\text { 3-Kironi } \\
\text { 3-Hysan } \\
\text { 4-Kironi } \\
\text { 4-Hysan } \\
\end{array}$ & $\begin{array}{l}36.15 \mathrm{~d} \\
48.07 \mathrm{a} \\
35.16 \mathrm{~d} \\
45.15 \mathrm{~b} \\
33.11 \mathrm{e} \\
41.22 \mathrm{c} \\
30.31 \mathrm{f} \\
35.53 \mathrm{~d} \\
27.93 \mathrm{~g} \\
29.66 \mathrm{f} \\
\end{array}$ & $\begin{array}{l}20.11 \mathrm{~b} \\
22.41 \mathrm{a} \\
19.13 \mathrm{be} \\
20.87 \mathrm{ab} \\
17.39 \mathrm{cde} \\
17.88 \mathrm{~cd} \\
16.68 \mathrm{de} \\
15.97 \mathrm{ef} \\
14.57 \mathrm{f} \\
12.41 \mathrm{~g} \\
\end{array}$ & $\begin{array}{l}76.79 \mathrm{bc} \\
72.35 \mathrm{ed} \\
82.18 \mathrm{a} \\
74.95 \mathrm{bed} \\
78.53 \mathrm{ab} \\
71.21 \mathrm{~d} \\
70.58 \mathrm{~d} \\
55.03 \mathrm{f} \\
65.28 \mathrm{e} \\
45.35 \mathrm{f} \\
\end{array}$ \\
\hline LSD (0.05) & 1.455 & 1.66 & 4.446 \\
\hline
\end{tabular}

$\mathrm{D}=$ Daily watering, $1=1$ Day without water, $2=2$ days without water, $3=3$ days without water, $4=4$ days without water.

Chlorophyll stability index (CSI): It was observed that the CSI of leaves was reduced gradually with the increase of drought treatments (Fig. 1). In both the varieties CSI was found significantly different. Among the treatments, dailywatered plants showed the maximum (92.04\%) CSI followed by 1 and 2 days drought, while 4-day drought cycle showed the minimum (75.14\%) CSI preceded 
by a 3-day drought cycle.The present observation revealed that the drought had reduced the CSI in sunflower leaves. The rate of reduction of CSI was found highest (18.4\%) in 4-day drought and the lowest (3.4\%) in 1-day drought cycle. In variety Kironi, under daily-watering to $1,2,3$, and 4-day drought cycles CSI values were reduced to $2.5,6.4,10.3$, and 14.2 percent, whereas the variety Hysan-55 showed 4.3, 8.6, 16.2, and 22.6 percent reduction, respectively. From these observations, it was evident that the chiorophylls in Kironi were more stable than the chlorophylls in Hysan-55. So, it reveals that the variety Kironi was more drought hardy than the variety Hysan-55 because of its high chlorophyll stability index. Similar results were obtained by Sanandachari (1978).

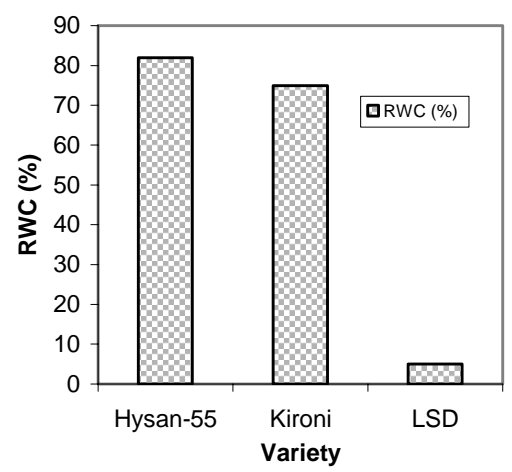

e

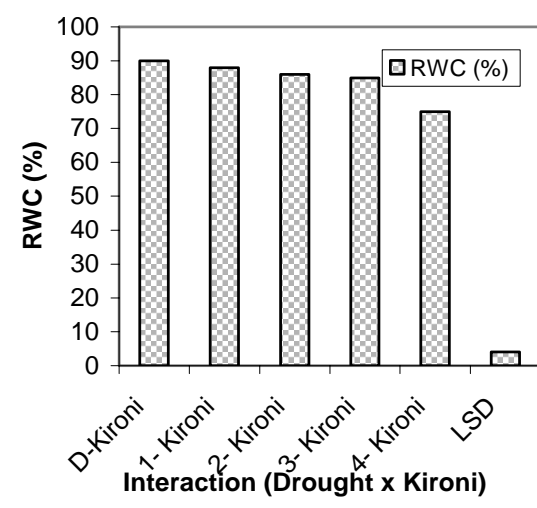

g

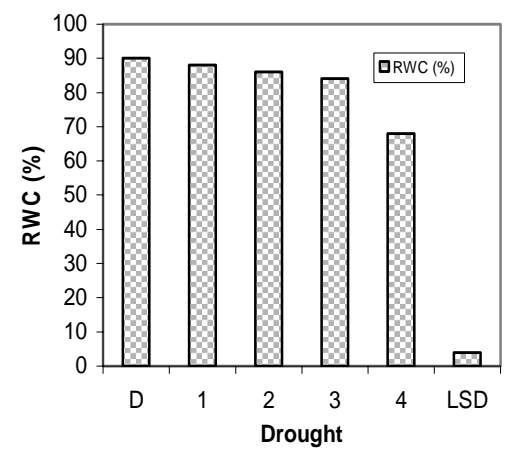

f
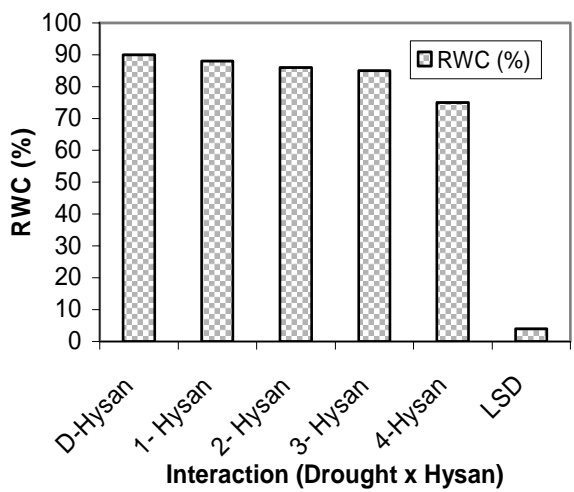

$\mathrm{h}$

Fig. 2. Relative water content (RWC) of leaf: for (a) Variety (b) Drought (c) Drought X Variety Kironi, (d) Drought X Variety Hysan-55.

LSD $(0.05)$ value for Variety $=2.87$

LSD (0.05) value for Drought $=2.63$

LSD (0.05) value for Drought $x$ Variety $=2.9$ 
Relative water content (RWC): It was evident that the RWC was decreased with the increasing in drought cycles (Fig.2). The rate of reduction was the lowest (3.62\%) under 1-day drought followed by 2-day drought, while the reduction was the highest (23.34\%) under 4-day drought, preceded by 3-day drought, treatments. Both the varieties produced significant differences between themselves.

Among the interaction between drought cycle and varieties, the variations in RWC was found significantly reduced. The rate of reduction in variety Kironi under daily-watering to 1, 2, 3, and 4-day drought cycles were 2.0, 4.52, 6.94, and 17.68 percent, whereas in the variety Hysan-55, the values were 5.23, 8.04, 13.05, and 30.11 percent, respectively. Velu and Palanisami (2002) reported that water stress sigrnficantly reduced relative water content of the plant. From this observation, it was evident that RWC in variety Kironi was higher compared to the variety Hysan-55. These better characteristics of drought resistance in Kironi might be due to its defensive mechanisms in physiological characters associated with drought tolerance.

Root volume: It was evident that drought treatments reduced the volume of root production (Table 3$)$. The daily watered plants produced the highest $(42.11 \mathrm{~g} / \mathrm{cc})$ amount of roots, while 4-day drought produced the minimum (28.80 g/cc). Varietal differences were also found significant where the variety Hysan-55 showed highest root volume than Kironi. Daily watering showed highest root volume at maturity in the variety Hysan-55. Among the interactions between drought and varieties, the rate of reduction under daily watering to 4-day drought cycles was 22.74 percent for Kironi, whereas in Hysan-55, the corresponding value was 38.30 percent. It was observed that the volume of the root was negatively affected by drought. Similar negative relations were also obtained in sunflower (Martin et al., 1993).

Tap root length: Drought treatments retarded the penetration of tap root to soil. The longest $(21.26 \mathrm{~cm})$ tap root was found in daily watered plants and the minimum $(13.49 \mathrm{~cm})$ in 4-day drought, but statistically insignificant. Both the varieties showed significant reduction in tap root length in response to stress treatments. Among the interaction between varieties and drought, the maximum tap root length was reduced with increasing stress treatments.

Total root length: It was evident that one day drought cycle produced the longest $(74.57 \mathrm{~m})$ roots, whereas, 4-day drought produced the shortest $(55.31 \mathrm{~m})$ root (Table 3). The variety Kironi reveals higher root length than Hysan-55. Interaction treatments were also found significant, where daily watered with variety Kironi gave higher root length but at par to 2-day drought of same variety. Such observation observed in sunflower roots by Sobrado and Turner (1986). 
Number of seeds: It was observed that the drought stress significantly reduced the number of seeds (Table 4). The highest number of seeds per head was in plants under daily watering (794.7), which was significantly different from other treatments. The reduction of seeds per head over control varied from 6.3 to 32.46 percent. The maximum reduction was found in 4-day drought. The reduction was quite low in case of 1-day drought where almost double seeds/head was obtained from the variety Hysan-55. There was significant variation between the varieties. Among the interactions between drought and varieties, the rate of reduction in variety Hysan-55 under control to 1, 2, 3, and 4-day drought cycles were 6.89, $14.95,25.11$, and 36.17 percent, whereas in the variety Kironi, the values were 5.13, 8.83, 15.35 and 24.14 percent, which was quite lower than those of Hysan55. Kazi et al. (2002) showed that number of seeds per head reduced due to long drought period in sunflower.

Table 4. Effect of drought on total no. of seeds per head, 100-seed weight and seed yield per plant.

\begin{tabular}{|c|c|c|c|}
\hline Treatments & $\begin{array}{c}\text { Total number of } \\
\text { seed per head }\end{array}$ & 100-seed wt (g) & $\begin{array}{c}\text { Seed yield/ } \\
\text { plant }(\mathrm{g})\end{array}$ \\
\hline \multicolumn{4}{|l|}{ Drought cycle } \\
\hline $\mathrm{D}$ & 794.7 a & $4.72 \mathrm{a}$ & $28.04 \mathrm{a}$ \\
\hline 1 & $744.5 \mathrm{~b}$ & $4.18 \mathrm{~b}$ & $24.76 \mathrm{~b}$ \\
\hline 2 & $690.8 \mathrm{c}$ & $3.77 \mathrm{c}$ & $21.91 \mathrm{c}$ \\
\hline 3 & $619.0 \mathrm{~d}$ & $3.46 \mathrm{~d}$ & $18.33 \mathrm{~d}$ \\
\hline 4 & $536.7 \mathrm{e}$ & $3.12 \mathrm{e}$ & $13.54 \mathrm{e}$ \\
\hline LSD (0.05) & 24.40 & 0.146 & 1.224 \\
\hline \multicolumn{4}{|l|}{ Variety } \\
\hline Kironi & 434.7 & 4.93 & 18.99 \\
\hline Hysan-55 & 919.6 & 2.77 & 23.64 \\
\hline "t-value" & $*$ & $*$ & $*$ \\
\hline \multicolumn{4}{|l|}{ Drought x Variety } \\
\hline D-Kironi & $486.7 \mathrm{f}$ & $5.90 \mathrm{a}$ & $23.37 \mathrm{c}$ \\
\hline D-Hysan & $1103.0 \mathrm{a}$ & $3.54 \mathrm{f}$ & $32.72 \mathrm{a}$ \\
\hline 1-Kironi & $461.7 \mathrm{fg}$ & $5.22 \mathrm{~b}$ & $20.94 \mathrm{~d}$ \\
\hline 1-Hysan & 1027.l b & $3.14 \mathrm{~g}$ & $28.59 \mathrm{~b}$ \\
\hline 2-Kironi & $443.7 \mathrm{gh}$ & $4.81 \mathrm{c}$ & $19.10 \mathrm{~d}$ \\
\hline 2-Hysan & $938.0 \mathrm{c}$ & $2.72 \mathrm{~h}$ & 24.92 c \\
\hline 3-Kironi & $412.0 \mathrm{~h}$ & $4.50 \mathrm{~d}$ & $16.85 \mathrm{c}$ \\
\hline 3-Hysan & $826.0 \mathrm{~d}$ & $2.41 \mathrm{i}$ & $19.80 \mathrm{~d}$ \\
\hline 4-Kironi & $369.3 \mathrm{i}$ & $4.21 \mathrm{e}$ & $14.67 \mathrm{f}$ \\
\hline 4-Hysan & $704.0 \mathrm{e}$ & $2.03 \mathrm{j}$ & $12.40 \mathrm{~g}$ \\
\hline LSD (0.05) & 34.51 & 0.254 & 1.801 \\
\hline
\end{tabular}

$\mathrm{D}=$ Daily watering, $1=1$ Day without water, $2=2$ days without water, $3=3$ days without water, $4=4$ days without water. 
100-seed weight: The plants under daily watered produced highest 100 -seed weight, whereas the 4-day drought produced the lowest (Table 4). Varieties showed significant variations in 100- seed weight where the variety Kironi was found much higher seed weight.

Among the interaction between drought and varieties, the rate of reduction of 100- seed weight, under daily watering to 4-day drought cycles in Kironi was 28.64 percent, whereas in the variety Hysan-55, the corresponding value was 42.65 percent. Similar results were reported in 100- seed weight by Vannozzi (1988) in sunflower. The reduction in seed weight due to drought may be attributed to reduction of photosynthesis, translocation of assimilates and also to the dehydration of grains.

Seed yield/plant: The plants treated with daily watering produced the highest (28.04 g) seed yield per plant (Table 4).There was trend to decrease yield with the increase of drought imposed where Hysan- 55 gave significantly higher seed yield than the variety Kironi.Varietal differences were found significant. The variety Hysan-55 under daily watering produced the highest yield (32.72 g). Among the interactions between varieties and drought, the rate of seed yield reduction in the variety Kironi under control to 4-day drought cycles was 35.33 percent, whereas in the variety Hysan-55, the corresponding value was 63.10 percent. Asl et al. (2003) cited that increase in the irrigation interval resulted in the reduction of the seed yield as increase of the percentage of infertile seeds. Though higher seed weight was recorded from the variety Kironi, but failed to show higher seed yield due to lower no. of seeds/plant. As a result, highest seed yield was obtained from the variety Hysan-55.

\section{Conclusion}

From the above observation, it may be concluded that the variety Kironi was found better than Hysan-55 in respect of physiological adaptation associated with yield under drought condition as drought was found more severe in Hysan-55 than in Kironi and the variety Kironi showed good performance to drought tolerance.

\section{References}

Arnon, I. 1975. Physiological principles of dry land crop production. In: Gupta, U.S. (ed.) Physiological aspects of dry land farming. Oxford \& IBH Pub., New Delhi, pp. 3-145.

Asl, K.K., D. Mazaheri, and S.A. Peighambari. 2003. Effect of four irrigation intervals on the seed yield and quantitive characteristics of sunflower cultivars. Iranian J. Agric. Sci. 34(2): 293-301.

Dougherty, C.T. 1973. Water relations of wheat as affected by irrigation and nitrogen fertilization. New Zealand J. Agril. Res. 16:12-18. 
Gimenez, C. and E. Fereres. 1987. Genetic variability in sunflower cultivars under drought II. Growth and water relations. Aust. J.Agric.Res. 3 7: 583-597.

Gomez, K.A. and A.A. Gomez. 1984. Statistical Procedure for Agricultural Research, International Rice Research Institute, John Wiley and Sons, New York, Chickester, Brisbane, Toronto, Singapore. pp. 139-240.

Kaloyereas, A.S. 1958. A new method of determining drought resistance. Plant Physiol. 33: 230.

Kazi, B.R., F.C. Oad, G.H. Jamro, L.A. Jamal, and N.L. Oad. 2002. Effect of water stress on the growth, yield and oil content of sunflower. Pakistan J. App. Sci. 2(5): 550552.

Martin, M., P. Molfetta, G. Vannozzi, and G. Zerbi. 1993. Sap flow-gas exchange and water relations in Helianthus annuus and $H$. argophyllus during drought cycles. Rivista-digronomia. 27(3): 191-197.

Morizet, J. P. Cruiziat, J. Chatenoud, P. Picot. and P. Lectlereq. 1984. Attempt to improve drought resistance in sunflower. Agronomic. 4(6): 577-585.

Rawson, H.M. and N.C. Turner. 1982. Recovery from water stess in five sunflower (Helianthus annuus L.) cultivars.II. The development of leaf area. Aust. J. Plant Physiol. 9: 449- 460.

Sanandachari, A. 1978. Studies on factors influencing drought resistance in sugarcane varieties. Andhra Agric. J. 25(5): 165-167.

Sobrado, M.A. and N.C. Turner. 1986. Photosynthesis, dry matter accumulation and distribution in the wild sunflower Helianthus petiolaris and the cultivated sunflower Helianthus annuus as influenced by water deficits. Oecologia 69(2): 141-187.

Velu, G. and K. Palanisami. 2002. Impact of moisture stress on growth and yield of sunflower. Madras Agric. J. 88 (10-12): 660-665.

Vannozzi, G.P., M. Baldini, and A. Benvenuti. 1988. The response of sunflower cultivar Solaris, sown late in the season, to different irrigation regimes. Sementi Elette 34(4): 19-23. 